\title{
Die koninkryk van God as sistematies-teologiese kategorie in die werk van J.A. Heyns
}

\begin{abstract}
Author:
Sarel J.L. Marais ${ }^{1}$

Affiliation:

${ }^{1}$ Department of Systematic

Theology and Christian

Ethics, University of Pretoria,

South Africa

Correspondence to:

Sarel Marais

Email:

sjlmarais@axxess.co.za

Postal address:

PO Box 28337, Sonlandpark

1944, South Africa

Dates:

Received: 11 Jan. 2011

Accepted: 14 May 2011

Published: 05 Dec. 2011

How to cite this article: Marais, S.J.L., 2011, 'Die koninkryk van God as sistematies-teologiese kategorie in die werk van J.A Heyns', Verbum et Ecclesia 32(1), Art. \#475, 9 pages. doi:10.4102/ve.v32i1.475

Note:

This article is based on research the author did for the PhD degree in Systematic Theology in the Department of Systematic Theology and Christian Ethics at the University of Pretoria. The title of the thesis was 'The kingdom of God as a systematic theological category in the work of JA Heyns'. The promoter was Prof. C.J. Wethmar.
\end{abstract}

C 2011. The Authors. Licensee: OpenJournals Publishing. This work is licensed under the Creative Commons Attribution License.
The kingdom of God as a systematic-theological category in the work of J.A. Heyns Heyns was probably the most noteworthy Afrikaans speaking theologian of the 20th century, considering the quantity of Afrikaans theological publications from his pen. It is a well known fact that he used the kingdom of God as a systematic-theological category that flows like a perennial river of opportunity through all of his writings. It created an opportunity to be consistent in both his systematic theology and in his ethics, show clearly how man and God can be coworkers in a dialogical relationship and to integrate philosophy with theology. Unfortunately, there was sometimes flooding, because he filled the kingdom of God with philosophical concepts and viewed it as an ontological cosmic-universal entity. His philosophical background also occasionally led to inadequate speculations in his theology and inadmissibly he didn't always use the Bible appropriately, although his doctrine of Scripture and hermeneutics were satisfactory. Lastly, his philosophical modus operandi helped him to differentiate between important theological concepts, which have problem solving abilities.

\section{Inleiding}

Die beoordeling van teologiese werk is glad nie 'n eenvoudige taak nie. Die objektiwiteitseis wat aan 'n beoordelaar gestel word, is na my mening 'n nastrewenswaardige, maar onbereikbare ideaal. 'n Mens kan nie anders as om 'n skrywer se werk subjektief, vanuit jou eie verwysingsraamwerk, wat onder andere jou eie konfessionele oortuigings, jou tradisie, jou lewens- en wêreldbeskouing en jou Skrifbeskouing insluit, te beoordeel nie. Boonop speel intellektuele vermoëns, psigososiale faktore, spiritualiteit, persoonlikheid, ervaring en vele meer, ook nog 'n beduidende rol. Daar word ongelukkig ook nie beskik oor 'n onfeilbare, altyd geldige, meetinstrument, kriteria of model, wat gebruik kan word in die beoordelingsproses nie (Marais 2010:11).

Daar sou geredeneer kon word dat die Heilige Skrif as meetinstrument gebruik moet word en dit sou 'n Gereformeerde uitgangspunt wees, maar wie se interpretasie van die Heilige Skrif sou dan die maatstaf wees? Daar sou ook aangevoer kon word dat die Belydenisskrifte of ons Gereformeerde tradisie as evalueringskriteria aangewend moet word. Ook in hierdie geval sou daar gevra kon word: wie se interpretasie van die Belydenisskrifte, of watter 'Gereformeerde' teoloog se interpretasie van die Gereformeerde tradisie moet gebruik word? Wanneer daar ook probeer word om die wetenskapsteoretiese- en wetenskapsfilosofiese problematiek te verreken, word die hele aangeleentheid net nóg meer ingewikkeld. Om alles te kroon, leef ons in ' $n$ snelveranderende konteks. Wat in hierdie dekade van kardinale belang blyk te wees, kan net in die volgende dekade geheel en al irrelevant wees (Marais 2010:11-12).

Van Huyssteen (1989) skryf ook oor hierdie problematiek en toon aan dat daar in die loop van die geskiedenis verskeie kriteria na vore getree het, wat 'n rol gespeel het in die evaluering van teologiese standpunte, modelle of paradigmas. Hierdie kriteria kan onder andere logiese positivisme, kritiese rasionalisme, kritiese realisme, of die vermoë van 'n teologie om probleme te identifiseer en op te los, wees.

In hierdie artikel is daar gekies vir probleemoplossingsvermoë as evalueringsinstrument in die bestudering van Heyns se werk. In kort, kom dit neer op die vraag: beskik Heyns se werk oor die vermoë om probleme op te los? In my bestudering van Heyns se werk, het ek ontdek dat hy sekere dogmatologiese onderskeidings gemaak het, wat baie nuttig in die teologie gebruik kan word, om sekere teologiese vraagstukke te beantwoord of teologiese probleme op te los, indien die konsepte verder verfyn en konsekwent toegepas word. Daar is veral twee onderskeidings wat Heyns geïdentifiseer het en in hierdie artikel aandag verdien. Dit is enersyds die onderskeid tussen die koninkryk van God en die heerskappy van God (Heyns 1972:49-50), maar andersyds ook die onderskeid tussen die realisering van die koninkryk van God en die eskatologiese vervulling van die koninkryk van God (Heyns 1986:48-49). 
Die invloed wat Heyns se voorliefde vir die filosofie op sy werk gehad het, word meestal negatief beoordeel. Dit is te verstane, aangesien dit, volgens Koekemoer, soms tot spekulasie aanleiding gegee het (1994:91) en andersyds ook soms gelei het tot die indra van filosofiese konsepte van buite af. Dit is my opinie dat dit onder andere ook ongelukkig daartoe bygedra dat Heyns die koninkryk van God as 'n ontologies, kosmies- universele grootheid beskou het, wat die ganse kosmos, stof, plant, mens, dier en engele insluit. Hierin was die Wysbegeerte van die Skeppingsidee van Stoker 'n bydraende faktor, soos Theron (1994:109) aangedui het en Jonker bevestig het (1994:18).

Hierdie filosofiese ingesteldheid, tesame met sy soms onnoukeurige Skrifhantering en die feit dat hy die koninkryk van God as 'n sistematies-teologiese kategorie gebruik het, was verantwoordelik vir die meeste kritiek op sy werk, soos dit na vore gekom het in Skrif en Kerk (1994:75-86); hierdie uitgawe is geheel aan Heyns se Teologie gewy.

Die koninkryk van God is 'n sistematies-teologiese kategorie in Heyns se werk, nie alleen omdat hy dit as die sentrale tema, of grondplan van die Bybel (Heyns 1994:10; Heyns \& Jonker 1977:171) en daarom ook van die teologie beskou nie (Heyns 1994:4, 11), maar ook omdat dit vir hom 'n metodologiese uitgangspunt en sleutel is, wat sy werkswyse, of modus operandi bepaal (Heyns 1986:38-67). Hierdie sentrale-temateologie en Skrifbeskouing het kritiek van Jonker, Theron en Le Roux tot gevolg gehad, veral omdat daar geredeneer word dat die Bybel nie net een sentrale tema het nie en dat so ' $n$ benadering tot subjektiewe en selektiewe redusering aanleiding kan gee (Jonker 1994:18; Theron 1994:116; Le Roux 1994:45). Heyns het ook gewaarsku teen 'n geslote sisteembouery met 'n logies-geforseerde struktuurformasie, waarin die veelsydigheid en verskeidenheid van God se openbaring in 'n eenheidskema, wat volledig vreemd aan sy wese is, ingewring word (Heyns 1992:33-34). Die koninkryk van God is, daarenteen, vir Heyns nie vreemd aan die wese van God se openbaring nie; inteendeel, dit is vir hom die skopus, gerigtheid, brandpunt, blikrigting, sleutel, of hart van die Skrif (Heyns 1983:66-67, 70). Aangesien hy dit as die taak van die dogmatiek beskou om, gelei deur die Heilige Gees, die sistematiek in die Skrif te ontdek en konkreet na vore te bring (Heyns 1992:34), is dit verstaanbaar dat hy vir hierdie sentrale-tema-denkraamwerk of paradigma gekies het, wat ook as metodologiese sleutel deur hom aangewend word, en dat die koninkryk van God dus 'n sistematiesteologiese kategorie in sy werk is (Marais 2010:10, 170, 484).

Le Roux en Wethmar het ook aangedui dat dit sy filosofiese agtergrond, -voorliefde en -werkswyse was wat hom gehelp het om oor die algemeen deurgaans konsekwent te bly, sodat sy werk 'n duidelike konsekwentheid kon vertoon (Le Roux 1994:29; Wethmar 1994:66). Hierdie standpunt behoort as ' $n$ veralgemening beskou te word, aangesien dit nie beteken dat daar geen inkonsekwenthede in Heyns se werk is nie. Na my mening het die filosofie ook daartoe bygedra dat Heyns noukeurig kon formuleer, logies kon dink en ook belangrike onderskeidinge kon identifiseer. Indien hierdie onderskeidinge verfyn word, beskik dit boonop ook oor die vermoë om teologiese probleme op te los (Marais 2010:552-553). Ons behoort dit positief te waardeer, aangesien dit daarop dui dat Heyns se filosofiese agtergrond, -ingesteldheid en -werkswyse nie net negatiewe gevolge gehad het nie.

In ons tyd speel ekumene 'n groter wordende rol en kan dit selfs dreig om in ekumenisme te ontaard! In 'n ekumenistiese konteks word dogmatiek dikwels verwaarloos, aangesien leerstellige kwessies te maklik tot skeuring en verdeeldheid aanleiding kan gee, wat nie bevorderlik vir ekumene is nie. Crafford wys daarop dat Heyns teen ' $\mathrm{n}$ negering van die belydenis gewaarsku het, maar tegelyk ook 'n verabsolutering van die belydenis afgewys het. In dié verband oordeel Crafford dat Heyns, met sy standpunte oor Skrif, waarheid en belydenis, ' $n$ waardevolle bydrae gelewer het om die ekumeniese gesprek oor konfessies sinvol te maak (Crafford 1994:83). Dit is ook deur Williams bevestig en duidelik aangetoon (Williams 2006:395-396).

Alhoewel Heyns dus onder skerp kritiek deurgeloop het oor die wyse waarop hy sy dogmatiek beoefen het, veral as gevolg van die filosofiese inslag wat sy teologie kenmerk en hoofsaaklik die invloed van die wysbegeerte van die Wetsidee en die daaruit voortvloeiende wysbegeerte van die Skeppingsidee van Stoker (Theron 1984:12, 15, 141; Jonker 1994:17; Le Roux 1994:41), is die bydrae wat Heyns gelewer het tot teologievorming op eie bodem nogtans fenomenaal en merkwaardig. Strauss (2002:170) skryf waarderend dat Heyns se drieledige Teologiese Etiek tot op datum die volledigste en omvattendste werk van hierdie aard in Afrikaans is. $\mathrm{Na}$ sy mening verdien dit steeds deeglike bestudering. Al sluit nuwe omstandighede ook kritiek op sy ouer wordende antwoorde in, doen dit egter, volgens Strauss, geensins afbreuk nie aan die grondliggende waarde van Heyns se prinsipiële denke, ook vir ons tyd.

Vervolgens gaan die onderskeid tussen die heerskappy van God en die koninkryk van God enersyds en die realisering van die koninkryk van God en die eskatologiese vervulling van God se koninkryk andersyds, onder die vergrootglas geplaas en verfyn word. Daarna gaan daar kortliks aangedui word hoe ' $n$ konsekwente handhawing van hierdie onderskeidinge gebruik kan word, om moontlike oplossings vir teologiese vraagstukke te kan bied. Daarmee word beslis nie gepleit vir 'n denkraamwerk wat van buite af op die Skrif afgeforseer moet word nie, want dan sou dieselfde kritiek wat teen Heyns se teologie ingebring is, ook weer hier geldig wees. Die verfyning van hierdie onderskeidings is maar net ' $n$ poging om begrippe wat in die Bybel en in die teologie gebruik word, nog duideliker te omlyn of te beskryf. Sodoende kan ander perspektiewe ook geopen word, wat verdere nadenke en navorsing kan stimuleer en boonop ook ander moontlike oplossings vir teologiese vraagstukke, na vore kan bring. 


\section{Die heerskappy van God}

Die eerste onderskeid wat aan die orde kom, is die onderskeid tussen die heerskappy van God en die koninkryk van God. Heyns het raakgesien dat hierdie twee begrippe wat met mekaar korreleer, nie identies is nie en nie na presies dieselfde saak verwys nie. Tog gebruik geleerdes soos Pannenberg (1977:25) en Du Toit (1974:48) hierdie twee begrippe asof dit sinonieme of wisselterme is. Selfs ook in die Nuwe Lewende Vertaling word die begrip 'heerskappy van God' gebruik, waar eerder 'koninkryk van God' vertaal moes word in Matteus 13:31 (Marais 2010:174). Al identifiseer Heyns hierdie onderskeid, handhaaf hy dit ongelukkig nie konsekwent nie en het hy ook die twee begrippe soms as sinonieme of wisselterme gebruik (Heyns 1972:51). Heyns noem die heerskappy van God die transendent subjektiewe korrelaat en die koninkryk van God die immanent subjektiewe korrelaat (Heyns 1972:49-50).

Na my oordeel is die heerskappy van die drie-enige God ' $n$ ontologies, kosmies-universele werklikheid wat volledig, onaantasbaar en onafhanklik van ewigheid tot in ewigheid bestaan en nie gerealiseer hoef te word nie (Marais 2010:176, 194). Dit beteken nie dat God se heerskappy 'n statiese werklikheid is nie; God is dinamies besig om te heers, sonder dat iets of iemand Hom kan onttroon.

Volgens Heyns is die feit dat God, die Vader, God, die Seun en God, die Heilige Gees van ewigheid af en tot in ewigheid regeer en heers, in so 'n mate 'n wesenskenmerk van God, dat dit goedskiks by die ander eienskappe van God (NGB:1) gevoeg sou kon word. Hierdie heerskappy strek onafhanklik oor alles en almal, selfs ook oor hulle wat dit nie wil erken nie (Heyns 1982:34).

\section{Die koninkryk van God}

Ek beskou die koninkryk van God as 'n werklikheid wat oral bestaan waar wedergebore kinders van God in Hom glo en aan Hom gehoorsaam is (Marais 2010:196-197) en daarom is 'die koninkryk van God' 'n enger begrip as 'die heerskappy van God' (Marais 2010:197).

Aangesien Heyns nie altyd die onderskeid tussen die heerskappy van God en die koninkryk van God konsekwent handhaaf nie en ook beïnvloed is deur die Wysbegeerte van die Skeppingsidee van Stoker, definieer Heyns, volgens my oordeel verkeerdelik, die koninkryk van God in ontologies kosmies-universele kategorieë, naamlik: die koninkryk van God is sy heerskappy oor en die gehoorsame aanvaarding daarvan, deur sy onderdane: stof, plant, dier, mens en engele (Heyns 1994:10).

Dit is tans my mening dat indien die onderskeid tussen die heerskappy van God en die koninkryk van God konsekwent gehandhaaf word, daar geredeneer sou kon word dat die heerskappy van God wel ontologies en kosmies-universele afmetings aanneem en ewigdurend is. Die heerskappy van God kan dus nie gerealiseer word nie, maar die koninkryk van God daarenteen, is ' $\mathrm{n}$ realiserende werklikheid, wat eskatologies vervul sal word. Vir die mens word burgerskap van die koninkryk van God bepaal deur die verlossingswerk van die Messias. Toegang tot die koninkryk van God is beperk tot wedergeborenes, wat uit genade vir Jesus Christus in die geloof aangeneem het, tot bekering gekom het en uit dankbaarheid vir hulle verlossing, aan die Koning van die heelal gehoorsaam is. Vir hulle het die koninkryk van God 'n werklikheid in hulle persoonlike lewens geword. Vir hulle is die koninkryk van God dus gerealiseer (Marais 2010:384385).

Ons sou ook die gehoorsame engele wat nie saam met die duiwel tot ' $n$ val gekom het nie hierby kon inreken, maar om stof, plant en dier ook hierby in te sluit, soos Heyns gedoen het, reduseer die soteriologiese aspek van die koninkryk van God. Heyns beklemtoon self dat toegang tot die koninkryk van God beskore is vir hulle wat wedergebore is (Heyns 1981:277). Verder word die lewensingesteldheid van die koninkryksburgers onder andere deur aanbidding en verheerliking van hulle Vader en Koning gekenmerk (Marais 2010:218). Wedergeboorte en aanbidding vind tog nie in die sfeer van stof, plant en dier op dieselfde wyse plaas as by die mens, wat na God se beeld geskep is en 'n vrye wil en keuse het nie. Daarom beskou ek Heyns se ontologiese en universeel-kosmiese siening van God se koninkryk as 'n oorspanning van die koninkryksbegrip.

Daar is wel voorbeelde van personifikasie, waar stof plant en dier betrek word in die toejuiging, lof en aanbidding van God, soos byvoorbeeld in Psalm 98, wat soos Psalm 47, 93, 96 en 97 ook 'n Troonbestygingspsalm is. Daarin word God se Koningsheerskappy besing (Kraus 1972:677; Anderson 1983:690-693). Hieruit sou afgelei kon word dat stof plant en dier ook deel uitmaak van die koninkryk van God, soos Heyns dit sien, maar personifikasie is 'n digterlike stylfiguur, wat meestal figuurlik funksioneer en nie altyd letterlik te vertolk is nie; riviere kan tog nie letterlik hande klap nie. Die skepping is wel onderworpe aan God se Koningsheerskappy en reageer gehoorsaam op Sy bevel en is volkome onder God se beheer. Dink maar naas die skeppingsverhale (Gen 1 en 2) ook aan die natuurwonders:

- die tien plae in Egipte (Eks 7-12)

- God laat vir Israel op droë grond deur die see loop, terwyl die Egiptenare verdrink (Eks 14)

- 'n groot vis sluk vir Jona in en spoeg hom na drie dae weer uit (Jona 1:17-2:10)

- Bileam se donkie praat met hom (Num 22:28-30)

- Jesus loop op water (Matt 14:22-33)

- Jesus maak storms stil (byvoorbeeld in Matt 8:23-27)

- Christus sorg vir uitsonderlike visvangste (byvoorbeeld in Joh 21:6)

- Jesus betaal selfs belasting met behulp van 'n silwermuntstuk in ' $n$ vis se bek (Matt 17:27)!

Ek twyfel daarenteen of Johannes die Doper en Jesus Christus stof plant en dier ook in gedagte gehad het, soos wat hulle die verlossing van die mens in die oog gehad het, toe hulle gesê het: 'Bekeer julle, want die koninkryk van die hemel het naby gekom' (Matt 3:2, 4:17); (Marais 2010:260, 299). Dit 
beteken nie dat ons die skepping moet onderwaardeer of verwaarloos nie; inteendeel, dit is die mens se opdrag om as beelddraers van God en sy verteenwoordigers op aarde, oor die skepping te heers en dit te bewerk en te bewaar (Gen 1:28, vergelyk ook Heyns 1972:24).

\section{Die realisering van die koninkryk van God}

Die tweede onderskeid wat Heyns geïdentifiseer het en wat oor probleemoplossingsvermoë beskik, is die onderskeid tussen die realisering van die koninkryk van God en die eskatologiese vervulling van die koninkryk van God. Volgens Heyns is die koninkryk van God 'n realiserende werklikheid. Voor die sondeval was die koninkryk van God en die heerskappy van God ewe groot in omvang, maar na die sondeval van die duiwel en sy volgelinge en later ook die mens, het die koninkryk van God kleiner geword as die heerskappy van God, aangesien God se heerskappy nie meer orals en deur almal gehoorsaam aanvaar is nie. Boonop het daar 'n anti-ryk ontstaan, waarin die duiwel as koning poog om stelling in te neem teenoor God. Naas God se koninkryk probeer die duiwel om vir homself 'n koninkryk op te rig wat in stryd met God en sy koninkryk is (Vergelyk Heyns 1981:167).

Dit is my oortuiging op hierdie stadium dat in die tydperk tussen die sondeval en die verlossingswerk van Jesus Christus, die koninkryk van God slegs daar teenwoordig was waar God se heerskappy deur gelowiges in Jesus Christus gehoorsaam aanvaar is. Vanweë die sondige natuur van die mens en sy totale verdorwenheid na die sondeval, was die koninkryk van God in hierdie tydperk ver verwyder en karig teenwoordig en was offerpraktyke om skuldvergifnis te verkry en weer deel aan die koninkryk van God te kon kry, noodsaaklik. Die koninkryk moes dus toenemend gerealiseer word (Marais 2010:230-241).

Met die inkarnasie van die Seun van die Mens en sy verlossingswerk, het die realisering van die koninkryk van God ' $n$ nuwe dimensie gekry, danksy die volmaakte gehoorsaamheid van die Seun van God aan die heerskappy van ons Vader en Koning. Deur Sy volmaakte, selfopofferende gehoorsaamheid, het die koninkryk van God naby gekom. Elkeen wat deur die Vader uitverkies is, deur die Heilige Gees wedergebore is en Jesus Christus in die geloof as Verlosser aangeneem en tot bekering gekom het, ontvang nie alleen vergifnis van hulle sonde en die ewige lewe nie, maar word ook uit dankbaarheid daarvoor, gehoorsame burgers in God se koninkryk (Marais 2010:240-269). Ongelukkig beteken dit nie dat hulle eensklaps heilig en sondeloos word en nooit ooit weer ongehoorsaam is nie. Hulle moet teen ongeloof, versoekings, die sonde en hulle sondige natuur in hulle eie lewe stry, maar ook teen vervolging, die bose, dwaalleringe en selfs sondige samelewingsstrukture (Marais 2010:270-283). Deur voortgaande bekering moet hulle biddend oorwinning daaroor behaal en sodoende word die koninkryk God intensief of kwalitatief gerealiseer (Marais 2010:203, 259-262). Heyns wys ook daarop dat die realisering van die koninkryk van God deur stryd gekenmerk word
(Heyns 1981:168-169). Gelukkig is dit, volgens Heyns, nie ' $n$ verlore stryd nie, want Jesus Christus het reeds die oorwinning behaal en daarom is die uitslag van die stryd seker en is dit reeds deur God bepaal (Heyns 1981:168-169, 1986:62; kyk ook Marais 2010:381-382).

Namate hierdie getal gelowige en gehoorsame kinders van God toeneem, word die koninkryk van God toenemend ekstensief of kwantitatief gerealiseer (Marais 2010:240, 283$286,306)$. Daarom het elke gelowige 'n missionêre opdrag en verantwoordelikheid om medewerkers van God te wees in die uitbreiding van sy koninkryk (Marais 2010:244, 374, 548). Hierdie missionêre karakter van God se koninkryk en die daarmee gepaardgaande medeverantwoordelikheid van die burgers van die koninkryk, tesame met die onmisbare rol wat gebed daarin speel, is onder andere van die aspekte, wat na my oordeel, meer aandag in Heyns se werk sou kon geniet (Marais 2010:548).

Al word die koninkryk van God dus 'alreeds' hier en nou intensief en ekstensief gerealiseer, is die koninkryk van God ongelukkig 'nog nie' ten volle vervul nie. Daarom word hierdie tydperk gekenmerk deur 'n 'alreeds', maar 'nog nie', spanningsveld (Marais 2010:450, 475-476).

\section{Die eskatologiese vervulling van God se koninkryk}

Met die wederkoms van die Seun van die Mens en die daarmee gepaardgaande oordeelsdag en die koms van die nuwe hemel en aarde, word hierdie 'alreeds', maar 'nog $n i e^{\prime}$ spanning opgehef en word die koninkryk van God eskatologies op die Godbestemde tyd deur God self vervul. Dan sal die buitelyne van die heerskappy van God en die buitelyne van die koninkryk van God weer saamval, soos wat dit heel aan die begin, voor die sondeval, was. Die duiwel en sy anti-ryk wat aan hom gehoorsaam en dus aan God ongehoorsaam was, word dan deur God veroordeel en gestraf vir ewig en altyd (Marais 2010:232, 394, 486).

Die burgers van God se koninkryk sal daarenteen met die eskatologiese vervulling van die koninkryk van God, deel in die ewige oorwinning en hulle gehoorsaamheid aan hulle Vader en Koning sal volmaak wees. Vir ewig en altyd sal hulle vir God gehoorsaam kan dien, verheerlik en aanbid en daarom sal die onderskeid tussen die heerskappy van God en die koninkryk van God verval, omdat dit weer identies sal wees (Marais 2010:384-385, 450). Heyns beklemtoon ook dat gehoorsaamheid ' $n$ uiters belangrike rol in die eskatologiese vervulling van God se koninkryk speel. Hy stel ' $n$ omvattende gehoorsaamheid vir die ganse kosmos in die vooruitsig, waarin gehoorsaamheid nie verdwyn nie, maar opgeneem word en tot volheid ontplooi word (Heyns 1972:69-70).

\section{Die vermoë om probleme op te los as kriterium}

Die onderskeidinge wat Heyns geïdentifiseer het, naamlik: die onderskeid tussen die heerskappy van God en die 
koninkryk van God enersyds en die onderskeid tussen die realisering van die koninkryk van God en die eskatologiese vervulling van die koninkryk van God andersyds is aan die orde gestel en verfyn. Daarom kan daar nou voortgegaan word om die vermoë tot probleemoplossing, as kriterium te geruik om een van die aspekte van die waarde van hierdie onderskeidings aan die lig te probeer bring.

Die teologiese probleme wat ons hiervoor kan gebruik, is:

- Die lydingsvraagstuk.

- Kan die mens die wederkoms bespoedig of vertraag?

- Die 'Nah-erwartung' [nabye verwagting].

\section{Die lydingsvraagstuk}

Met die lydingsvraagstuk word daar verwys na die lydingsprobleem en God se aandeel of rol in menslike lyding. Met die sonde het ook lyding die wêreld binnegedring en daaraan is alle mense onderwerp. Volgens Heyns, staan God nie magteloos teenoor lyding nie, maar Hy heers daaroor en gebruik dit selfs in sy diens (Heyns 1982:495).

Dit is Heyns se mening dat die duiwel ook lyding met sy mag, van God ontleen en binne die ruimte, deur God aan hom toegestaan, kan gebruik om mense te versoek en hulle teen God in opstand te probeer aanhits. Heyns beklemtoon verder ook dat net soos wat daar aan die begin van die skepping geen lyding was nie, net so sal daar met die eskatologiese vervulling van die koninkryk van God, wanneer die nuwe hemel en die nuwe aarde 'n werklikheid geword het, ook geen lyding meer wees nie (Heyns 1982:495).

Na Heyns se oordeel, kan die mens lyding nie maar net aanvaar of daarteen in verset kom nie. Die gelowige mens moet ook nie primêr fokus op die einde van lyding nie, maar eerder op die doel daarvan. Dít kan, na Heyns se oordeel, alleen beantwoord word langs die weg van die geloof in die lydende Kneg van God. Heyns noem dit 'n logoterapeutiese benadering (Heyns 1982:503). Ons geloof verplaas ons nie uit ons lyding uit nie en dit gee ook nie vir ons al die antwoorde op ál die lydingsvrae nie, maar dit open volgens Heyns vir ons die dienskonteks van lyding (Heyns 1982:498).

Deur ons geloof ontdek ons dat ons nie in ons lyding alleen is nie. God se betrokkenheid in elke moontlike situasie beteken vir Heyns dat die situasie nooit onbeheerbaar sal word nie. In die tweede plek moet daar ook, na Heyns se oordeel, begryp word dat alles nooit te veel sal word nie; ons sal nie daaronder breek, of ooit verloor wat God aan ons geskenk het, naamlik, die verlossing in Jesus Christus nie. Volgens Heyns is dit juis hierdie wete wat ons, soos hy dit noem, nie in onvrugbare rasionalistiese redenasies van immanente kousaliteit laat vasval en in wanhoop laat eindig nie (Heyns 1982:498-499).

Hierdie geloofsdaad maak ons, aldus Heyns, ook diensbaar. Diensbaar in ons gebede, in ons voorbidding, maar ook in ons medelye. Gelowiges is geroep om oor die ganse wêreld te heers en dit sluit ook die werklikheid van lyding in. Die heerskappy begin met en kry gestalte in ons geloof in Jesus
Christus. Vir Heyns is lyding eers sinvol wanneer dit ' $n$ mens nie verlam en passief maak nie, maar jou eerder oproep tot verset, tot aktiewe en beplande, herstrukturerende optrede in 'n wêreld wat deur Jesus Christus van sy lyding bevry is. Na Heyns se oordeel moet die Christen 'n heilige onvrede teenoor lyding vertoon en aktief meewerk aan die eliminering van lydingveroorsakende gebeure en strukture (Heyns 1982:500).

In die heerskappy oor lyding en die eensaamheid wat dit wil veroorsaak, speel gesprek vir Heyns 'n belangrike rol en wel in tweërlei gestaltes: in gebed met God, waarin die gelowige sy lot oor sy lyding kan bekla en voorbidding kan doen vir almal wat ly, asook in bemoedigende dialoog met die naaste met wie daar liefdevolle medelye moet wees (Heyns 1982:500-501).

Heyns sal waarskynlik nie net onthou word vir sy talle publikasies nie, maar veral ook vir die wyse waarop hy hierdie waarhede in sy eie lewe prakties uitgeleef het en daadwerklik gepoog het om lydingveroorsakende samelewingsstrukture in ' $\mathrm{n}$ moeilike oorgangsituasie in Suid-Afrika te verander. Williams het dit in sy proefskrif aan die lig gebring, waar hy onder andere geskryf het dat Heyns na homself as ' $n$ brugbouer verwys het. Williams vervolg dat Heyns self besef het dat ' $n$ brug ook soms deur mense gebruik word om op te trap. Ten spyte daarvan dat mense soms op hom 'getrap' het, omdat hulle van hom verskil het, het Heyns homself sonder reserwe gegee, om versoening te probeer bewerkstellig, nie net tussen kerke en gelowiges nie, maar ook in die breë SuidAfrikaanse samelewing (Williams 2006:412).

Heyns het dus nie alleen die kern van die lydingsvraagstuk probeer raak formuleer nie, maar ook daadwerklike pogings aangewend om ' $n$ verskil te maak. Vervolgens gaan daar gepoog word om aan te toon dat die tersaaklike onderskeidings ook nuttig aangewend kan word in ons worsteling met hierdie probleem. Hoe is dit moontlik dat daar lyding by God se kinders kan wees, as God, hulle Vader, regeer? Skeptici kan wonder hoe 'n God van liefde kan toelaat dat sy kinders ly. Die feit dat lyding ook by gelowiges bestaan, kan nie weggeredeneer word nie. Dit wil ook voorkom asof geen enkelvoudige of eenvoudige verklaring daarvoor aangebied kan word nie, maar in die lig van die dogmatologiese onderskeidinge in die Koninkryksleer, wat hier uitgewys is, kan ander perspektiewe ook ontgin word.

In die eerste plek moet daar beklemtoon word dat God oor alles heers. Sy heerskappy strek ook oor lyding. Hy skep die ruimte vir lyding en Hy bepaal die grense daarvan. Hy kan dit selfs in diens neem. Hy kan lyding gebruik om ons geloof te toets. Hy kan lyding gebruik om ons tot bekering te vermaan. Hy kan selfs lyding gebruik om ons te vorm soos 'n pottebakker klei vorm, of om soos ' $n$ wingerdboer ons te snoei, sodat ons nog meer vrugte kan dra. Dit beteken nie dat Hy altyd direk vir lyding verantwoordelik is nie. Soms bring die mens lyding oor homself. Soms word lyding veroorsaak deur die gevolge van die sonde in die algemeen en soms as gevolg van 'n spesifieke sonde. Soms word lyding veroorsaak 
deur die werkinge van die duiwel en die bose magte, maar dit alles kan nie ' $n$ einde maak aan die feit dat God ook oor lyding regeer nie (Marais 2010:462-463).

Dit sou vergelyk kon word met ' $\mathrm{n}$ groot Skaakmeester wat ten volle in beheer van die skaakspel is. Sy opponent het die vryheid om tientalle opsies uit te oefen en sy skaakstukke te posisioneer, binne die reëls van die spel. Die groot Skaakmeester het daarteenoor sy skaakstukke só strategies geposisioneer, dat die uitslag van die spel reeds seker is, ten spyte van watter opsie sy opponent ook al sou besluit om uit te oefen. Vir elke moontlikheid wat die opponent kan laat realiseer, het die Skaakmeester klaar ' $\mathrm{n}$ antwoord gereed. Selfs al lyk dit asof die Skaakmeester gaan verloor, omdat 'n baie waardevolle 'Skaakstuk' opgeoffer moet word, toon Hy juis sy beheer oor die spel en sy opponent bevind homself in skaakmat met die daaropvolgende skuif (Marais 2010:463).

Hierdie metafoor, soos enige ander metafoor, het ook maar sy beperkinge. Die waarde van hierdie metafoor is egter daarin geleë dat God se opperheerskappy beklemtoon word en dat daar ruimte vir vryheid ook vir God se teenstander(s) bestaan. ' $n$ Ruimte wat ook deur Hom beheer word, maar nie volkome deterministies nie (Marais 2010:463).

Wat die koninkryk van God en lyding aanbetref, staan lyding in verband met die feit dat God se koningsheerskappy nog nie deur almal gehoorsaam aanvaar word nie. Lyding bestaan omdat die koninkryk van God nog nie eskatologies vervul is nie. Omdat die buitelyne van God se heerskappy en die buitelyne van God se koninkryk nog nie saamval nie. Die tekens van die tye, wat meestal ook met lyding gepaard gaan, herinner ons enersyds daaraan dat die eskatologiese vervulling van God se koninkryk op pad is, maar skep ook andersyds paranetiese ruimtes waarbinne ongelowiges en ongehoorsames opgeroep kan word tot bekering. Daarom is daar ' $n$ direkte verband tussen lyding en stryd in die koninkryk van God. Deur te stry teen onder andere die anti-ryk, die sonde, die bose, versoekings, maar ook lyding, werk die gelowiges gehoorsaam, maar ook met medelye en empatie mee, as bondgenootskaplike medewerkers, aan die realisering van God se koninkryk. Dit moet egter nie horisontalisties en humanisties verstaan word, soos verkeerdelik in die bevrydingsteologie gedoen word nie. Dit moet, na my oordeel, steeds hamartologies en soteriologies geïnterpreteer word (Marais 2010:464).

Die onderskeid tussen die heerskappy van God en die koninkryk van God open juis ook vir ons die dimensie van troos en die dimensie van verantwoordelikheid. Die feit dat God regeer is vir ons ' $n$ vertroostende wete; Hy sal nie toelaat dat ons bo ons kragte beproef word nie. Hy hou lyding binne perke. Die feit dat ons ' $n$ strydende verantwoordelikheid het om teen die lyding in die wêreld te stry en om liefdevolle medelye en empatie met ons naaste te hê, kom alles binne die blikveld van die koninkryk van God. Die koninkryk van God roep ons juis op tot gehoorsaamheid en tot die nakom van ons verantwoordelikhede, wat passiwiteit met wortel en tak uitroei, sodat die koninkryk van God toenemend gerealiseer kan word, totdat dit eskatologies deur God vervul kan word (Marais 2010:464-465).

\section{Kan die mens die wederkoms bespoedig of vertraag?}

Waarom het die wederkoms nog nie plaasgevind nie? Ons lees dan op verskeie plekke in die Bybel dat Jesus gou gaan kom (Sien Heyns 1981:408; Marais 2010:422-424), maar ons lees ook dat die wederkoms nie gaan plaasvind voordat die volle getal uitverkorenes tot geloof gekom het nie (Marais 2010:429). Heyns het ook in 'n ongepubliseerde manuskrip oor die Nuwe Testament en die koninkryk van God aangedui dat die Messias ook kan talm om weer te kom, aan die hand van enkele gelykenisse (Heyns 1994:59).

Beteken dit dat die mens, vanweë ons gebrek aan gehoorsaamheid en sendingywer, verantwoordelik gehou kan word vir die feit dat die wederkoms nog nie plaas gevind het nie? Kan ons deur ons missionêre arbeid, of die gebrek daaraan, die wederkoms bespoedig of vertraag of selfs ad infinitum uitstel? (Marais 2010:431).

Na my oordeel kan die onderskeid tussen die realisering van die koninkryk van God en die eskatologiese vervulling van die koninkryk van God, ons help om die mens se aandeel en verantwoordelikheid in die uitbreiding van God se koninkryk beter te verstaan. Die mens is as bondgenootskaplike medewerker medeverantwoordelik vir die realisering van die koninkryk van God. Deur sy eie geestelike groei, toewyding, gehoorsaamheid en voortgaande bekerings, werk die mens mee aan die intensiewe of kwalitatiewe realisering van die koninkryk van God. Deur die mens se missionêre ywer en getuienis, deur woord én daad, werk die mens ook mee aan die ekstensiewe of kwantitatiewe realisering van die koninkryk van God. Daarom is daar 'n direkte verband tussen die mens se gehoorsaamheid en die realisering van die koninkryk van God en kan die mens inderdaad die realisering van die koninkryk van God bespoedig of vertraag (Marais 2010:470).

Wanneer dit daarteenoor by die eskatologiese vervulling van die koninkryk van God kom, waarvan die wederkoms van Jesus Christus van kardinale belang is, tree die mens op die agtergrond. God en sy ewige Raadsplan en sy beloftes aangaande die wederkoms, die nuwe hemel en die nuwe aarde en die oordeelsdag, tree dan op die voorgrond. God sorg self dat dit op die bestemde tyd, wat slegs aan die Vader alleen bekend is, plaasvind (Marais 2010:467-468).

Daarom kan die mens nie die wederkoms of die daarmee gepaardgaande eskatologiese vervulling van die koninkryk van God, bespoedig of vertraag deur gehoorsaamheid en missionêre ywer en -arbeid, of die gebrek daaraan nie (Marais 2010:468-469). Die mens kan wel die tempo waarteen die koninkryk van God gerealiseer word, bespoedig deur sy gehoorsaamheid en missionêre werk, of vertraag deur ' $\mathrm{n}$ gebrek daaraan (Marais 2010:470).

God het dus nie die datum van Jesus Christus se wederkoms los gemaak van die mens se verantwoordelikheid in die 
realisering van sy koninkryk nie, maar Hy het ook nie die eskatologiese vervulling van sy koninkryk afhanklik gemaak van die mens se verantwoordelikheid nie (Marais 2010:441, 470; vergelyk Heyns se ongepubliseerde manuskrip 1994:16).

\section{Die 'Nah-erwartung' [nabye verwagting]}

Daar is talle tekste in die Bybel wat getuig dat die koninkryk naby of in die leeftyd van daardie geslag sal kom. Dit word die sogenaamde 'Nah-erwartung' [nabye verwagting] genoem. Wanneer daar verkeerdelik gedink word dat hierdie teksverse verwys na die eskatologiese vervulling van die koninkryk van God en die daarmee gepaardgaande wederkoms, skep dit 'n uiters moeilike problematiek, want daar het al meer as 2000 jaar verloop en die wederkoms het steeds nie plaasgevind nie (Marais 2010:471).

Wanneer daarteenoor die onderskeid tussen die realisering van die koninkryk van God en die eskatologiese vervulling van die koninkryk van God konsekwent gehandhaaf word en daar geredeneer word dat die sogenaamde 'naby' tekste nie na die eskatologiese vervulling van die koninkryk verwys nie, maar wel na die realisering van die koninkryk van God, kan die 'Nah-erwartung' probleem daarmee sinvol hanteer word, want die koninkryk van God is 'n realiserende werklikheid, wat uiteindelik op die Godbepaalde tyd, eskatologies deur Hom vervul sal word (Marais 2010:474).

Verder moet daar ook in gedagte gehou word dat die koms van die koninkryk, die wederkoms van Jesus Christus en die eindtyd wat naby is, nie na presies dieselfde saak of gebeurtenis verwys nie en ook nie identiese, of sinonieme begrippe is nie. Deur hierdie begrippe duidelik van mekaar te onderskei, kan sommige skynbare teenstrydighede in die Skrif uit die weg geruim word en na die 'reeds', maar 'nog $n i e^{\prime}$ spanningsveld verplaas word. In dié verband is daar gedeeltes in die Heilige Skrif wat van kardinale belang is. Hierdie teksverse behoort ook te bewys dat dit belangrik is, om die onderskeid tussen die realisering van die koninkryk van God en die eskatologiese vervulling van die koninkryk van God, konsekwent te handhaaf.

In Matteus 16:28 lees ons: 'Dit verseker Ek julle: Daar is party van dié wat hier staan wat beslis nie sal sterwe voordat hulle die Seun van die mens in sy koninkryk sien kom het nie'. Hoe kon Jesus so 'n uitlating maak, as Hy nie die dag en die uur van die wederkoms geken het nie? Praat Hy in hierdie teksvers regtig van die wederkoms, of bedoel Hy dalk iets anders? Indien Jesus hier verwys het na die tydstip van sy wederkoms, sou Hy inderdaad ' $n$ leuenaar en 'n vals profeet genoem kon word. Dit sou ondenkbaar en selfs Godslasterlik wees! 'n Moontlike uitweg sou wees om te redeneer dat Jesus nie verwys het na ' $n$ letterlike en fisiese sterwe nie, maar ' $n$ geestelike sterwe. Die wat in Hom glo, het die ewige lewe en sal in alle ewigheid nooit sterf (geestelik) nie, maar daar is niks in die konteks te vinde, wat hierdie moontlike verklaring bevestig nie. As Jesus nie van die wederkoms praat nie, wat bedoel Hy dan met die frase: 'die Seun van die mens in sy koninkryk sien kom'? Daar word vermoed dat Hy daarmee verwys na die realisering van die koninkryk van God en nie na die eskatologiese vervulling van die koninkryk van God of die wederkoms nie. In hierdie teksvers gaan dit om die realisering van die koninkryk van God, wat die omstanders en luisteraars gesien en beleef het, in die verlossingswerk van Jesus Christus en selfs in die latere hemelvaart. Die koms van die koninkryk gaan soteriologies gesproke, gepaard met die wedergeboorte, geloof en bekering van die gelowige. Mense wat dus deur Jesus Christus verlos is, het inderdaad die koms van die koninkryk beleef! Dit gaan dus nie in Matteus 16:28 oor die eskatologiese vervulling van die koninkryk van God nie, alhoewel die voorafgaande vers, Matteus 16:27, duidelik en ondubbelsinnig na die wederkoms van Jesus Christus verwys. Dit was dus nie die wederkoms of die eskatologiese vervulling van die koninkryk van God wat nog in die leeftyd van Jesus se toehoorders sou plaasvind nie, maar die realisering van die koninkryk van God wat, na my mening, hoofsaaklik soteriologies plaasvind. Dit word bewys deur die feit dat Jesus nie in vers 28 weer van die wederkoms melding maak nie, maar van die koms van die koninkryk. Verder moet daarop gelet word dat die konteks waarin hierdie vers voorkom, te doen het met die navolging van Jesus Christus, wat die soteriologiese toegang tot die koninkryk van God in die oog het. Jesus se hoorders het dus inderdaad die koms van die koninkryk aanskou, voordat hulle gesterf het, omdat hulle gesien en beleef het hoedat mense deur hulle geloof in Jesus Christus verlossing ontvang het (Marais 2010:476-478).

Hierdie vermoede word bevestig wanneer 'n vergelykende studie gedoen word van die sinoptiese Evangelies, waar gelykluidende uitsprake van Jesus vermeld word, naamlik: Matteus 24:34, Markus 13:30, asook Lukas 21:32. Daar lees ons: 'Dit verseker Ek julle: Nog in die leeftyd van hierdie geslag, sal (dit alles: Matteus en Markus) (al hierdie dinge: Lukas) gebeur'. Al drie Evangelies vertoon opvallende, byna woord-vir-woord ooreenkomste. Soos in die vorige teksvers, waarin verwys is na 'party wat hier staan nie sal sterwe voordat hulle dit gesien het nie', word in hierdie drie teksverse gepraat van 'in die leeftyd van hierdie geslag'. Waar Jesus in Matteus 16:28 gepraat het van 'die koms van die Seun van die Mens in sy koninkryk', praat Hy hier van 'dit alles' of 'al hierdie dinge'. Dit alles, of al hierdie dinge, verwys na die voorafgaande gedeeltes, wat begin met die vrae van die dissipels in Matteus 24:3: 'Sê vir ons, wanneer sal hierdie dinge gebeur en wat sal die teken van U koms en van die einde van hierdie wêreld wees?' Die dissipels wou twee dinge by Jesus weet. Eerstens, wou hulle weet wanneer 'hierdie dinge' sal gebeur, waarmee hulle verwys het na die direk voorafgaande profesie van Jesus dat die tempel verwoes sal word, iets wat in ongeveer 70 N.C., inderdaad in die leeftyd van daardie geslag, gebeur het. In die tweede plek wou hulle weet wat die teken van Jesus se koms en die einde van hierdie wêreld sal wees. In Sy antwoord aan sy dissipels het Jesus nie probeer voorspel op watter tydstip die wederkoms en die daarmee gepaardgaande einde van die wêreld sou wees nie. Deur melding te maak van die vals profete, die vals christusse, die oorloë en die gerugte van oorloë, die verdrukking, vervolging, afvalligheid, en die ander sogenaamde 'tekens van die tye', wou Hy ook 
nie ' $\mathrm{n}$ aanduiding van die tydstip van die wederkoms gee nie; inteendeel, Hy sê dat dit moet kom, maar dit is nog nie die einde nie (Matt 24:6) en dat dit soos geboortepyne is (Matt 24:8). Die einde sal eers kom wanneer al die nasies die getuienis van die evangelie van die koninkryk, wat oor die hele wêreld verkondig moet word, gehoor het (Matt 24:14). In Matteus 24:32-33 en in Markus 13:28 en 29 verwys Jesus sy toehoorders na die voorbeeld van die vyeboom. Net soos wat ' $n$ mens weet dat die somer naby is wanneer ' $n$ vyeboom begin bot, net so moet hulle weet dat die dinge waarvan Hy in die profetiese rede gepraat het, die sogenaamde 'tekens van die tye' ook 'n aanduiding is dat die tyd naby is. Lukas gee vir ons 'n nadere aanduiding van wat met 'die tyd' wat naby is, bedoel word, wanneer hy skryf in 21:31: 'Net so moet julle ook, wanneer julle hierdie dinge sien gebeur, weet dat die koninkryk van God naby is' (Marais 2010:476-478).

Oor die dag en die uur van die wederkoms, sê Jesus in die daaropvolgende gedeelte (Matt 24:36-44) dat dit onbekend aan almal, behalwe die Vader is en dat dit skielik en onverwags sal kom. Daarna vertel Hy die gelykenisse van die getroue en ontroue slawe (Matt 24:45-51), van die tien meisies (Matt 25:1-13) en die gelykenis van die muntstukke (Matt 25:14-30) om te verduidelik dat daar wel tyd kan verloop voordat die wederkoms en die daarmee gepaardgaande einde van die wêreld, of die eskatologiese vervulling van die koninkryk van God, soos dit hier genoem word, gaan plaasvind (Marais 2010:478-479; vergelyk Heyns se ongepubliseerde manuskrip 1994:59).

Nog ' $n$ teksgedeelte wat verreken sal moet word, is Johannes 21:20-23, waarin Petrus van Jesus wou weet wat van Johannes gaan word, nadat Jesus te kenne gegee het met watter dood Petrus vir God sou verheerlik. Jesus se antwoord aan Petrus was: 'As ek wil hê dat hy in die lewe moet bly totdat ek weer kom, is dit nie jou saak nie. Volg jy My!' Hierdie uitspraak van Jesus is verkeerdelik geïnterpreteer en daar is as gevolg daarvan ' $n$ gerug versprei dat Johannes nie sou sterwe nie, maar Johannes beklemtoon in vers 23 dat Jesus nie gesê het dat Johannes nie sou sterwe nie, maar dat die omstandighede van Johannes se toekoms, of hy nou tydens die wederkoms steeds gaan lewe, (of nie), nie iets is waaroor Petrus bekommerd moet wees nie. Petrus en saam met hom eintlik al die gelowiges, moet Jesus volg, ongeag 'n toekoms van vervolging. So gesien, help die onderskeiding tussen die realisering en die eskatologiese vervulling van die koninkryk van God ons, om nie die dag en die uur van die wederkoms te verwar met die koms of realisering van die koninkryk van God nie (Marais 2010:479-480).

Die tydstip van die realisering van die koninkryk van God het dus al reeds in die leeftyd van daardie geslag aangebreek, maar die tydstip van die eskatologiese vervulling van die koninkryk van God is niealleen onbekend nie, ditisookiets wat eers later kan aanbreek. Die onderskeid tussen die realisering van die koninkryk van God en die eskatologiese vervulling van die koninkryk van God is dus uiters noodsaaklik, al is dit nie uitdrukkings wat woordeliks in die Bybel voorkom nie, omdat dit ons help om hierdie skynbare moeilikhede op te los en ander perspektiewe te open. Daarmee word nie gesê dat die 'Nah-erwartung' problematiek oorvereenvoudig moet word nie, maar wel dat dit in die perspektief van die dogmatologiese onderskeid tussen die realisering van die koninkryk van God en die eskatologiese vervulling van die koninkryk van God, nie 'n onoorkombare struikelblok hoef te wees nie (Marais 2010:480).

\section{Slotsom}

'n Perfekte, volmaakte en foutlose teologie is nog nooit geskryf nie, want die enigste volmaakte en foutlose mens, Jesus Christus, was nie 'n teoloog in ons wetenskaplike verstaan daarvan nie en Hy wou ook waarskynlik nie vir ons 'n sistematies-teologiese uiteensetting van sy denke gee nie. Daarom sal ons baie maklik teen enige teoloog kritiek kon uitspreek en foute kon uitwys wanneer ons 'n kritiese evaluering van sy of haar werk moet aanpak. Dit maan ons om versigtig en nederig te wees en ook bewus te wees van ons eie subjektiewe oortuigings.

Die vraag wat ons hier egter aan die orde wou stel is die vraag na die waarde wat Heyns se teologie tot die Teologiebeoefening toegevoeg het. Dit wou ons doen aan die hand van die probleemoplossingsvermoëkriterium. Dit sou inderdaad beskou kon word as 'n pragmatiese vertrekpunt wat die modus operandi van hierdie navorsing bepaal het. Sistematiese teologie of Dogmatiek se waarde is nie alleen te vinde in die uitleg of formulering van konfessionele waarhede nie, maar ook in die wyse waarop dit bruikbaar benut kan word om antwoorde op moeilike teologiese vraagstukke te vind.

Dit is my oortuiging dat Heyns tog wel deur sy werk 'n sinvolle bydrae gelewer het. Sy teologiese werk is, ten spyte van die filosofiese invloede, nuttig en bruikbaar, aangesien dit ' $n$ interessante perspektief verleen in die soektog na antwoorde op moeilike teologiese vraagstukke. Bo en behalwe die groot hoeveelheid hoogstaande gehalte en hoogaangeskrewe teologiese publikasies wat hy in Afrikaans die lig laat sien het, is daar ook bruikbare dogmatologiese onderskeidinge wat hy geïdentifiseer het, wat wel ook oor die nuttige vermoë beskik om probleme te identifiseer en op te los.

\section{Literatuurverwysings}

Anderson, A.A., 1983, The Book of Psalms [Die Boek van Psalms], Volume II, Psalms 73-150, The New Century Bible Commentary, Reprinted, February 1983, William. B. Eerdmans, Michigan, MI.

Crafford, D., 1994, 'Johan Heyns as ekumeniese figuur', Skrif en Kerk 15(1), 75-86.

Du Toit, S., 1974, Openbaringsgeskiedenis van die Ou Testament, 4de hersiene en uitgebreide druk, 1ste herdruk, Pro Rege-Pers, Potchefstroom.

Heyns, J.A., 1994, 'Die Koninkryk van God - Grondplan van die Bybel', Skrif en Kerk 15(1), 1-12.

Heyns, J.A., 1994, “n Weerwoord', Skrif en Kerk 15(1), 156-176.

Heyns, J.A., 1994, 'Die Nuwe Testament en die Koninkryk', 'n ongepubliseerde manuskrip wat deel sou uitmaak van ' $n$ groter werk van J.A.Heyns oor die koninkryk van God, wat ongelukkig vanweë die sluipmoord nie voltooi is nie.

Heyns, J.A., 1992, Inleiding tot die Dogmatiek aan die hand van die Nederlandse Geloofsbelydenis, NG Kerkboekhandel, Pretoria.

Heyns, J.A., 1988, Teologiese Etiek, Deel 2/2, Sosiale Etiek, NG Kerkboekhandel, Pretoria. 
Heyns, J.A., 1987, 'Respons op F.E. Deist, Relativisme en absolutisme: Kan dit oorkom word? Oor "Bybelse" en "dogmatiese" teologie', UPTS 4, Ou Testament Teologie: Gister vandag en Môre, NG Kerkboekhandel, Pretoria,

Heyns, J.A., 1986, Teologiese Etiek, Deel 2/1, Sosiale Etiek, NG Kerkboekhandel, Pretoria.

Heyns, J.A., 1985, Mediese Etiek, NG Kerkboekhandel, Pretoria.

Heyns, J.A., 1983, Brug tussen God en mens, 2de druk, NG Kerkboekhandel, Pretoria.

Heyns, J.A., 1982, Teologiese Etiek, Deel 1, NG Kerkboekhandel, Pretoria.

Heyns, J.A., 1981, Leer my... Naasteliefde, Daan Retief Uitgewers, Pretoria.

Heyns, J.A., 1981, Dogmatiek, 2de druk, NG Kerkboekhandel, Pretoria.

Heyns, J.A., 1981, Die Mens. Bybelse en Buite-Bybelse Mensbeskouinge, 2de druk, Sacum, Bloemfontein.

Heyns, J.A., 1977, Die Kerk, NG Kerkboekhandel, Pretoria

Heyns, J.A., 1976, Die Nuwe Mens Onderweg: oor die tien gebooie, 3de druk Tafelberg, Kaapstad.

Heyns, J.A., 1975, Teologie van die revolusie, Tafelberg, Kaapstad.

Heyns, J.A., 1972, Lewende Christendom: 'n Teologie van gehoorsaamheid, Tafelberg, Kaapstad.

Heyns, J.A., 1971, Die huidige stand van die Gereformeerde Teologie in Nederland en ons verantwoordelikheid, Publikasies van die Universiteit van Pretoria, Nuwe Reeks, nr. 57, Universiteit van Pretoria, Pretoria.

Heyns, J.A., 1969, Wie fyner maal, Nasionale Boekhandel, Kaapstad.

Heyns, J.A., 1968, Wie Dieper Delf, Nasionale Boekhandel, Kaapstad.

Heyns, J.A., 1968, Christus en Socrates Sterwe. Gesprekke oor die Geloof, Pro RegePers, Potchefstroom

Heyns, J.A., 1967, 'Die Kerk as diens aan die koninkryk', Annale Universiteit van Stellenbosch, 31(B1), Universiteit van Stellenbosch, Stellenbosch.

Heyns, J.A., 1967, Denkers deur die eeue, Tafelberg, Kaapstad.

Heyns, J.A., 1966, Die evangelie in krisis, Tafelberg, Kaapstad.

Heyns, J.A., 1964, Die Teologiese Antropologie van Karl Barth vanuit WysgerigAntropologiese Oriëntering, proefskrif, Potchefstroomse Universiteit vir Christelike Hoër Onderwys, Tafelberg, Kaapstad.

Heyns, J.A., 1963, Die Chiliasme of die Duisendjarige Ryk, NG Kerkuitgewers, Kaapstad.

Heyns, J.A., 1963, 'Karl Barth se Beskouing insake die Verhouding van Teologie en Filosofie', NGTT, 4(4), 229-239.

Heyns, J.A., 1962, 'Kerk en Kerkregering by Karl Barth', NGTT 3(4), 515-533.
Heyns, J.A., 1961. "...en lei ons nie in versoeking nie", NG Kerkuitgewers, Kaapstad. Heyns, J.A., 1959, Gods vertrouelinge: gedagtes oor die gelykenis van die talente, Pro Rege-Pers, Potchefstroom.

Heyns, J.A., 1959, Die onsterflikheid van die siel, NG Kerkuitgewers, Pretoria.

Heyns, J.A., 1955, Karl Barth: wie is hy en wat wil hy? Sacum, Bloemfontein.

Heyns, J.A., 1953. 'Die Grondstruktuur van die Modalistiese Triniteitsbeskouing', Vrije Universiteit, Amsterdam.

Heyns, J.A. \& Jonker, W.D., 1977, Op weg met die Teologie, 2de druk, NG Kerkboekhandel, Pretoria.

Jonker, W.D., 1994, 'In gesprek met Johan Heyns', Skrif en Kerk 15(1), 13-26.

Koekemoer, J.H., 1994, 'Dogmatiek in die rigting van die Gereformeerde Ortodoksie, Skrif en Kerk 15(1), 87-94.

Kraus, H.J., 1972, Psalmen, 2. Teilband, Psalmen 64-150, Biblischer Kommentar Altes Testament [Bybelse Kommentaar van die Ou Testament], Neukirchener Verlag, Vluyn.

Le Roux, J.H., 1994, 'God se brug na die mens: iets goddeliks of iets mensliks? ('n Kort woord oor Johan Heyns se Skrifleer)', Skrif en Kerk 15(1), 27-51.

Marais, S.J.L., 2010, 'Die koninkryk van God as sistematies-teologiese kategorie in die werk van J.A Heyns', ongepubliseerde PhD-proefskrif, Universiteit van Pretoria.

N.G. Kerk, 1987, Ons Glo...: Die Drie Formuliere van Eenheid en Ekumeniese Belydenisse, 4de druk, NG Kerkuitgewers, Kaapstad.

Pannenberg, W., 1977, Human Nature, Election, and History [Menslike natuur, uitverkiesing en geskiedenis], Westminster Press, Philadelphia.

Strauss, S.A., 2002, 'Die verhouding tussen dogmatiek en etiek in die teologie van J.A. Heyns', In die Skriflig 36(2), 169-183.

Theron, D.F., 1994, “n Gesprek oor die teologie van Heyns', Skrif en Kerk 15(1), 108117.

Theron, D.F., 1984, 'Die Koninkryk van God in die Teologie van J.A. Heyns', ongepubliseerde DD-proefskrif, Universiteit van Suid-Afrika.

Van Huysteen, J.W., 1989, Theology and the justification of faith: Constructing Theories in Systematic Theology [Teologie en die regverdiging deur geloof: Die konstruksie van teorieë in Sistematiese Teologie], transl. H.F. Snijders, William B. Eerdmans, Grand Rapids, MI.

Wethmar, C.J., 1994, 'Wetenskaplikheid en konfessionaliteit van die teologie: Enkele gesigspunte in verband met die teologiebegrip van JA Heyns', Skrif en Kerk 15(1) 65-74.

Williams, H.H., 2006, 'JA Heyns en die Nederduitse Gereformeerde Kerk en Apartheid', ongepubliseerde proefskrif, Universiteit van die Vrystaat. 